\title{
Collaboration between Pre-School Institution and Family
}

\author{
(1)Liga Paula ${ }^{1}$ Dr. sc. soc.; Linda Valaine-Rohnana ${ }^{2}$ Bs. sc. soc. \\ Latvia University of Life Sciences and Technologies, Latvia \\ Liga.Paula@1lu.lv'; valaine.linda@gmail.com²
}

\begin{abstract}
Collaboration in all educational institutions including pre-school establishments is a topical issue especially within the framework of competence-based learning approaches. The aim of the study was to find out what is the collaboration between pre-school and parents in relation to the acquisition of pre-school curriculum which in Latvia is defined as compulsory for children in the age of 5 to 6 (7) years. A quantitative approach was used in the research and two surveys were conducted in April 2020. Both parents and pre-school teachers who work with 5 to 6 (7) year old children were asked to participate in the on-line survey, which was developed in the platform VisiDati.lv. Analysis of collaboration between parents and preschool was based on the framework of six types of school-family-community involvement created by J.L. Epstein. The research analysis revealed that pre-school teachers and parents have different understandings of the child's need for parental support so that parents can get involved and promote the acquisition of compulsory pre-school curriculum. Teachers and parents have clear communication channels to fully exchange the necessary information, however, to form collaboration, teachers have difficulties in developing individual curricula in some cases. The research results are useful to understand what hinders cooperation and how to improve it.
\end{abstract}

Keywords: socialization, pre-school education, collaboration, family.

\section{Introduction}

Building collaboration and defining values in schools is a topical issue for educational institutions today, which has become relevant with the introduction of competency-based learning approaches. The need of cooperation is focused on the pre-school, primary and further education stages (Reynolds et al., 2017), where the pre-school guidelines indicate the cooperation process as one of the principles to implement the curriculum - the child, teachers, parents or the child's legal representatives and development cooperation, involving parents or the child's legal representatives to support the child's learning and providing regular feedback on the child's performance and achievements (Noteikumi par valsts..., 2018). The topicality of the research is defined by the unclear process of activities, how the cooperation between school, family and a child can be methodically developed and practically implemented.

As A.G. Degangi with co-authors in their research state, collaboration between educators and families can illuminate different views on parenting practices, daily life, family structure and roles, disability and its causes, early intervention, helpful relationships and communication with others, all of whom are influenced by culture, values and beliefs (Degangi et al., 1994). Despite various problems and conflict situations, the teacher must do everything possible to develop cooperation with parents, because they are essential in the child's learning process (Barile, 2020). N. Barile refers to her own approaches in working with parents which includes activity, kindness, explaining goals and outcomes to parents, developing an action plan, solving problems, starting with a positive comment, taking the lead in the conversation, maintaining communication on both children achievements and solving problems (Barile, 2020). S. Koviene in her research has discovered that parents in pre-school institutions mostly expect support from specialists such as the psychologist, social pedagogue, and nutritionist (Koviene, 2017). Albanian researcher A. Ecirli focuses on the significance of interaction between a family and pre-school institution (Ecirli, 2012). Both family and pre-school are the first significant socialization agents, therefore A. Ecirli believes that the family develops certain characteristics of a child which cannot be changed by the educational institution unless its cooperation with a family and parents in particular is based on common values. He also points out that the goals of the pre-school education include helping the child to develop physical, mental, emotional and social abilities by stimulating a healthy environment so necessary for the development of a child's personality. Pre-school develops children basic knowledge, skills and attitudes necessary for further schooling. This function of preschool education is important, especially for children from lower socio-economic backgrounds. From this perspective, pre-school contributes also to the education of parents that improves their knowledge in how to 
help children in the learning process at home. Parents are involved in assessing children's performance (Lin et al., 2021). To achieve effective collaboration, teachers must take into account the differences in the cultural background of each family, experience, and behaviour patterns (Ecirli, 2012).

Although the family is the child's primary socialization institute, today parents have high demands towards educational institutions to ensure children's socialization. One of the most important roles of pre-school education is to create a learning environment in which children can become a part of a social group. With the promotion of independence and the support of teachers, children develop their self-confidence, learn to interact with other peers, learn what compassion and respect are. Pre-school education plays an important role in social education, which emphasizes the importance of social and emotional learning, promotes the development of skills and is the basis for the process of self-awareness (Deans et al., 2017).

Cooperation is the result of shared values and norms, as well as compliant behaviour (Diekmann, Lindenberg, 2001). In relation to cooperation between parents and pre-school teachers, the focus should be on developing a common understanding of values and not on cooperation based solely on instructions, recommendations, or guidelines (Robbins, 2005; Vanaga, Balode, 2016). Parents may have differing opinions on teaching methods and approaches, and this may be a serious challenge for teachers as there are situations when child activities need to be coordinated with the parents' permission (Taurina, 2015). Parents must be a partner in the school, because parents also act as a child's teacher. It is even the case with teachers who are parents' partners while the children are in their care. While children are in school, teachers are involved in shaping children's thinking, attitudes and behaviours by collaborating with parents. Without parental support and cooperation, teachers' efforts and influence are limited (Yaşaroğlu, 2016; Reynolds et al., 2017). The pre-school guidelines define forms of cooperation between the institution and the family (Klauža et al., 2009), which are:

- individual (written, telephone or electronic communication, answers to questions, parents' invitation to school, individual consultations, home visit, discussions with parents);

- group (group parents' meeting, parents committee or council, group consultations);

- frontal (general meeting of parents; family evenings; school holidays; hiking, excursions; sporting events; joint attendance at cultural events; pedagogical education activities.

J. Badjanova and Dz. Ilisko refers to the need for a balanced and sustainable system of general education (Badjanova, Ilisko, 2014). In Latvia, since 90 s of the $20^{\text {th }}$ centuries, increasingly attention is paid to the child as an individual. Increased attention is paid to the child's interests, needs and well-being in society, which are related to the child's adaptation in the pre-school educational institution and later to the child's transition from pre-school to school (Āboltina, Černova, 2017). The aim of the study is to find out what is the collaboration between pre-school and parents in relation to the acquisition of pre-school curriculum which in Latvia is defined as compulsory for children in the age of 5 to 6 (7) years.

\section{Methodology}

A quantitative approach was used in the research and two surveys were conducted in April 2020. To reach the aim, the following research questions were defined:

1. What is the role of pre-school education institutions and a family in the process of children's socialization?

2. What are the expectations of the pre-school educational institutions and parents regarding the collaboration process?

3. What is the daily co-operation between pre-school and the family?

To answer these questions, both parents and pre-school teachers who work with 5 to 6(7) years old children were asked to participate in the on-line survey, which was developed in the platform VisiDati.lv and organized according to the methodological and ethical principles of the Internet survey (Roberts, Allen, 2015; Toepoel, 2016). Parents $(n=185)$ of children aged 5 to 7 years acquiring compulsory preschool education and teachers $(\mathrm{n}=130)$ who provide compulsory education were involved in the survey. Convenience sampling was applied in the study to reach more respondents from different regions of Latvia. The sample, however, is not representative, therefore the research results are indicative. Information about the survey was disseminated via social media platforms (such as Facebook, draugiem.lv) and via e-mailing to pre-schools. Separate questionnaires were designed for each target group 
comprising both the same and specifically formulated questions for the teachers and parents. Closed and open-ended questions were included in the survey. Only few men participated in the parents' survey and all respondents from the teacher group were women. The respondents were informed about the aim of the research, they were provided with contact information in case they had queries regarding the survey. According to the research ethics (Toepoel, 2016), participation in the survey was completely voluntary and anonymous. The results of the research were analysed only in an aggregated way and responses of both sample groups were compared where appropriate.

Analysis of collaboration between parents and preschool was based on the framework of six types of schoolfamily-community involvement (Figure 1) created by J.L. Epstein (Epstein, 2010; Sanders, Epstein, 1998).

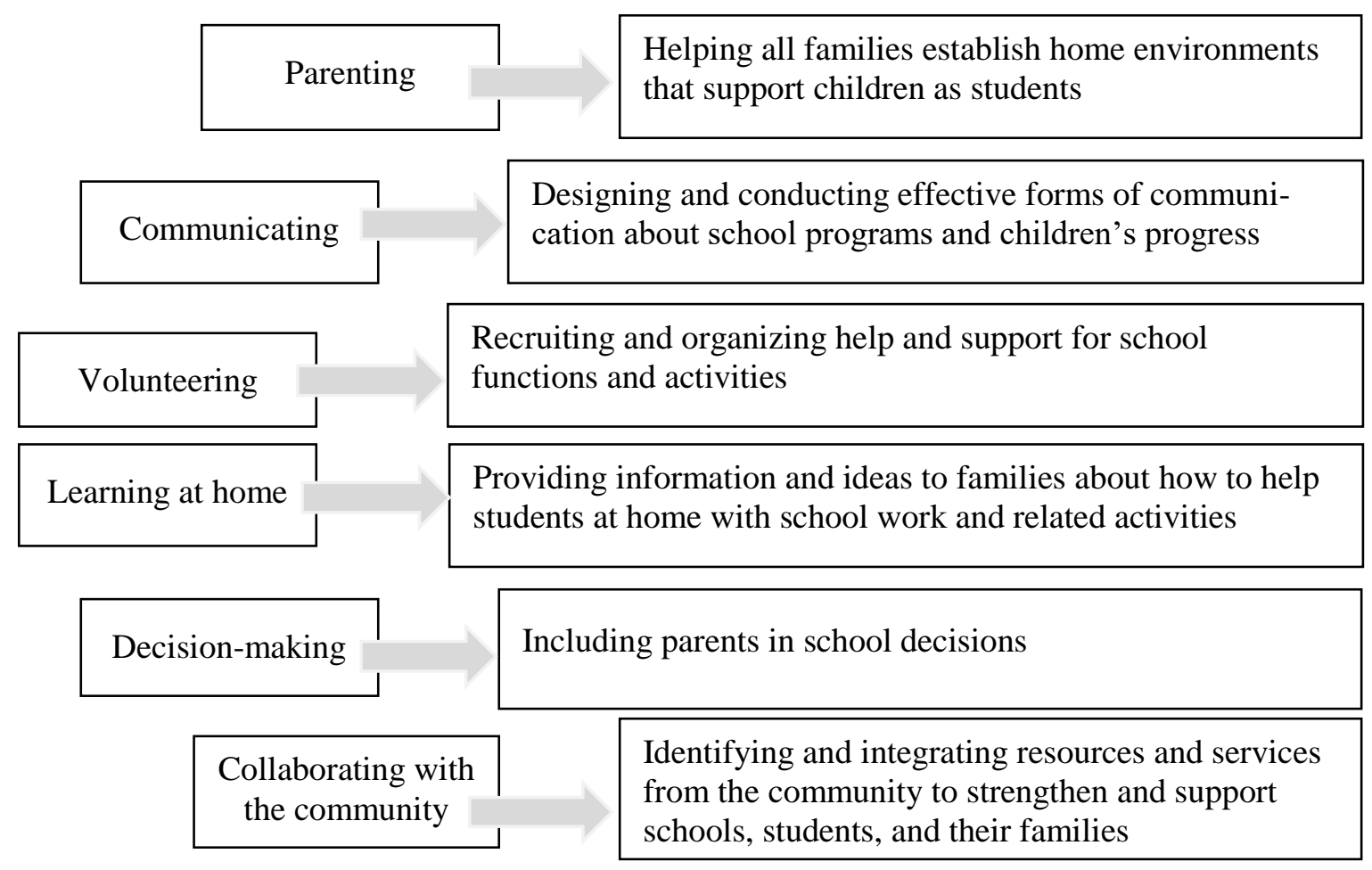

Figure 1. The six types of involvement (Sanders, Epstein, 1998; Epstein, 2010).

Survey questions were elaborated according to the six types of involvement (Figure 1). The same structural logic was maintained in data analysis.

\section{Results and Discussion}

To promote and create an appropriate learning environment at home, which would stimulate the acquisition of compulsory subject content, pre-school teachers need to educate the families and support them emotionally. This is how teachers can contribute to parenting greatly. In the survey, $51 \%$ of parents indicated that they would like to receive recommendations from the pre-school teachers on learning at home which is appropriate to the child's age and development, $27 \%$ of the respondents indicated that they would partially like to receive recommendations, and only $22 \%$ indicate that they do not want to receive teachers' recommendations. To provide necessary support to the 5 to 7 years old children in the acquisition of their subject in pre-school, $33 \%$ of teachers indicated that parents should primarily pay attention to the child's psychological development, $29 \%$ of teachers believed that attention should be paid to socialization process and only $17 \%$ of teachers indicated that parents should pay attention to learning the subject matter. Some teachers (12\%) pointed out that this is a complex measure and cannot be separated therefore parents should pay attention to the interaction of all types of support. Teachers' survey revealed the following: $43 \%$ of the respondents admitted that their pre-school institutions have developed precise recommendations for teachers on how to communicate, cooperate and solve various problems with parents, whereas $9 \%$ indicated that there are no such recommendations. The rest part of the respondents pointed out that pre-school institutions have developed partial recommendations for teachers on collaboration with parents. This indicates that there is no common concept and guidelines in the pre-school 
system as a whole, how pre-school teachers can better communicate with parents. Such recommendations for teachers may have been developed on the basis of an individual institution initiative.

According to J.L. Epstein (Epstein, 2010), communication between pre-school institution and the family is a two-way discussion and exchange about the schooling programs of educational institutions, educational achievements and children progress. In the survey, teachers pointed to a number of IT tools and solutions as the most common communication channels: pedagogical communication is organized through telephone calls, online communication platforms and apps such as WhatsApp, and e-mails (mentioned by $36 \%$ of the respondents). An equally important approach is individual teacher-parent faceto-face communication (mentioned by $35 \%$ of the teachers). Parents also mentioned that the main information exchange channels between the pre-school institution and the family are direct communication with a teacher (mentioned by $50 \%$ of the respondents) and IT solutions (mentioned by $32 \%$ of the parents). However, although the forms of communication are clear to users and at place, the content of the communication is important, which limits or encourages the result of cooperation. In the survey, $10 \%$ of parents indicated that they did not receive information from the pre-school institution about the child's achievements and skills to be developed, $49 \%$ indicated that they received it only if they asked, and $41 \%$ of parents acknowledged that they have received sufficient information from the pre-school institution.

Information exchange should be reciprocal and genuine to encourage mutual communication. However, $10 \%$ of the teachers indicated that they do not receive any true information about the child's individual development, family problems or other issues that affect the child's development and the teacher should pay attention to to promote an acquisition of the pre-school curriculum. Still, $79 \%$ of teachers indicated that this type of information is partially received when asked by the authority. Only $11 \%$ of the respondents admitted that the institution has information about the child's individual development, which allows to provide a necessary support. During the survey, the teachers referred to a number of issues, such as family problems, as the most common hidden information of parents that hinders the learning process in pre-school (Table 1).

Table 1

Examples of problems in families affecting the acquisition of knowledge and skills in pre-school

\begin{tabular}{|c|c|c|}
\hline Social/ family problems & Psychological problems & Physical problems \\
\hline $\begin{array}{l}\text { - Internal family problems (parental } \\
\text { divorce, single-parent family, dis- } \\
\text { agreements between parents, relation- } \\
\text { ships with other family members) } \\
\text { - Division of responsibilities between } \\
\text { parents (who is responsible for what) } \\
\text { - Everyday living conditions (financial } \\
\text { situation, place of residence, } \\
\text { environment). } \\
\text { - Ignoring recommended specialists (e.g., } \\
\text { do not visit a speech therapist, although } \\
\text { pre-school teachers recommend) }\end{array}$ & $\begin{array}{l}\text { - Child's behavioural } \\
\text { disorders (possible } \\
\text { medical causes } \\
\text { hyperactivity, autism) } \\
\text { - Psychological } \\
\text { atmosphere in the family } \\
\text { and during contacts with } \\
\text { other people } \\
\text { (psychological terror, } \\
\text { mobbing) }\end{array}$ & $\begin{array}{l}\text { - Health/ morbidity problems } \\
\text { (a child has been taken to pre- } \\
\text { school with signs of illness, but } \\
\text { this fact is hidden from } \\
\text { personnel) } \\
\text { - Child's physical abnormalities } \\
\text { were approved by a doctor that } \\
\text { has not been reported to pre- } \\
\text { school institution (e.g., } \\
\text { movement disorders) } \\
\text { - Violence (physical abuse of a } \\
\text { child, also physical abuse of } \\
\text { other family members) }\end{array}$ \\
\hline
\end{tabular}

Open-ended question was included in the survey to find out the problems what teachers faced in terms of collaboration with parents. Some pointed out that often parents do not seem to notice or even neglect the child's physical or psychological problems, which significantly affected teacher's work with a particular child. The reason was that parents had different views on the child's development and behaviour. For example, some parents did not observe significant deviations from the average norm in the child's posture, speech or motor skills. Consequently, teachers cannot develop an individual curriculum in time and find the most appropriate teaching approach, because the causes of the problems are not known. In some cases, teachers pointed to the trend to transfer responsibility from the family to the institution: parents tended to insist that there was no problem with the child's behaviour at home, but it was observed only in the institution thus suggesting that the teacher did not have the skills to deal with the child. 
The voluntary involvement of parents in activities organized by both pre-school institutions and other establishments promotes co-operation between pre-school and the family. More than one-third of the respondents (38\% of parents) have indicated that they followed the pre-school curriculum, $49 \%$ of the respondents did it sometimes, but $12 \%$ - did not follow it. The curriculum also includes various socialization activities involving children, family members and the institution. Almost $50 \%$ of the teachers assessed that the involvement of parents in various activities organized by the pre-school were satisfactory while $43 \%$ of the respondents indicated that it was satisfactory rather than unsatisfactory. There are activities and knowledge that parents through their voluntary involvement can promote at home (e.g., through learning activities together with the child). One quarter of the teachers $(25 \%)$ indicated that parents should explain various household issues and everyday peculiarities to their children and they must answer their questions. Teachers (18\%) also mentioned that children themselves should be allowed to explore things of interest; $40 \%$ of teachers indicated that reading fairy tales promotes learning process. Parents in their survey approved that they are happy to explain various everyday situations and answer questions asked by their children (14\%), teach letters and math (13\%), together attend various events such as theatre, concerts, sports games $(12 \%)$. Teachers drew attention to the need for parents to develop social skills and abilities and to train the child's independence as much as possible.

The voluntary involvement of parents is aimed at acquiring various social knowledge and skills, however, in pre-school there is a compulsory learning content that the child must acquire. To promote learning at home, pre-school should provide information to the family on how to successfully and appropriately promote learning at home. The analysis confirms that pre-school institutions and parents are happy to involve and participate in the implementation of the pre-school curriculum and 36 parents (out of 95) indicated that they had not encountered any problems, however, in some cases parents mention various problems that parents have to face while their child was in the pre-school curriculum (Table 2).

Table 2

Examples of problems that parents have faced while their children have acquired compulsory pre-school curriculum

\begin{tabular}{|c|c|c|}
\hline $\begin{array}{r}\text { Pro } \\
\text { socia } \\
\mathbf{S} \\
\end{array}$ & & \\
\hline $\begin{array}{l}\text { - Groups formed of children of } \\
\text { different ages } \\
\text { - Lack of specialists (e.g., } \\
\text { speech therapist) in } \\
\text { institution } \\
\text { - Disturbing behaviour of } \\
\text { other children } \\
\text { - Teacher's pedagogical skills } \\
\text { (lack of skills to teach } \\
\text { children and to solve } \\
\text { various problem situations) } \\
\text { - Unnecessary competition } \\
\text { between teachers } \\
\text { - Haste of the child }\end{array}$ & $\begin{array}{l}\text { the new competence-based } \\
\text { cient information about } \\
\text { works } \\
\text { sts to provide materials for } \\
\text { ig process what actually are } \\
\text { ailable for parents } \\
\text { f information from teachers }\end{array}$ & \begin{tabular}{|ll} 
- & $\mathrm{D}$ \\
- & $\mathrm{In}$ \\
& $\mathrm{d}$ \\
- & $\mathrm{L}$ \\
& $\mathrm{le}$ \\
& $\mathrm{sc}$ \\
- & $\mathrm{L}$ \\
& $\mathrm{cl}$ \\
- & $\mathrm{R}$ \\
& $\mathrm{pr}$ \\
- & $\mathrm{L}$ \\
& $\mathrm{d}$
\end{tabular} \\
\hline
\end{tabular}

These issues can be an obstacle to the process of building cooperation between pre-school institutions and families. Based on the obtained data, it can be concluded that parents are involved in various decisions that are binding on their children. More than half of parents $(63 \%)$ have indicated that they always attended parental meetings organized by the institution or have given an opinion on certain issues, whereas $25 \%$ were involved in decision-making at least once every six months but $10 \%$ - at least once a year.

Every family member is invited to support the educational institution by building family and community cooperation outside the institution. Pre-school establishments organize meetings, events, guest lectures, consultations with professionals and other activities in which parents participate, thus supporting their children. The process of cooperation between the two agents can be positive or negative. Teachers in 17 cases (out of 71) indicated that they did not face difficulties in forming and involving parents in joint 
out-of-institution cooperation activities (e.g., parents had to prepare the composition of natural materials, collect waste paper, collect natural materials with the child). However, 60 teachers emphasized the difficulties which they faced in organizing and involving parents as parents referred to their lack of spare time and too long working hours. Parents often when arrived to the event, were uninterested and without motivation to involve in activities together with their children. Negotiation with parents is considered a solution in such situations explaining how important parents' participation is for the children.

Assessing the collaboration between parents and pre-school institutions in general, $31 \%$ of teachers indicated that it is satisfactory while $59 \%$ of teachers believed that it is satisfactory rather than unsatisfactory. Parents in their survey referred to unclear information exchange channels $(26 \%)$, differences of opinion with other parents (23\%) and occupation with other things (17\%) as the biggest burden or reason for not participating in the joint cooperation process. Teachers named several examples of cooperation that reflected the positive impact of cooperation on a child's development and acquisition of knowledge in preschool. For example, for almost a year after a systematic conversation with a parent, a solution was found to move the child to a special education program. The parents were strongly opposed at first and did not want to cooperate, however, a result was thankful. In other cases, parents participated in joint clean-ups, thematic events, got involved in repairing old shelters, where children can play. Analysing the cooperation from different aspects, according to the results of the survey, the authors conclude that there is a mutual communication between pre-school institutions and the families. Joint pre-school and family cooperation are focused on the result that is in the best interests of the child. Problems can be solved positively through communication, individual approaches and negotiations, which are confirmed by both parents and teachers.

\section{Conclusions}

The result of the child's primary socialization in the family, entering the new social environment which is pre-school, reflects, on the one hand, the interaction of parental upbringing style and family norm boundaries, but, on the other hand, the child's personality traits and future development trends. The child's interest in learning and various activities at school is stimulated by interested parents who are motivated to cooperate with the group teacher, subject teachers, administration, social pedagogue, psychologist and other school personnel. Although curriculum developers may want to increase parental involvement, this is only possible if they provide teacher training and time to work with parents.

The research data analysis revealed that pre-school teachers and parents have different understandings of the child's need for parental support so that parents can get involved and promote the acquisition of compulsory pre-school curriculum. In the survey, half of the parents $(51 \%)$ pointed out that direct recommendations from the pre-school on learning subject at home (related to formal learning) would be needed, while teachers stressed out that to acquire the compulsory content qualitatively, parents should focus primarily on the child's psychological development and socialization.

Teachers and parents have clear communication channels to fully exchange the necessary information, however, to form collaboration, teachers have difficulties in developing individual curricula in some cases, because parents often withhold or do not provide true information about the child's individual, family or other problems affecting the child what makes it difficult to complete the curriculum. The voluntary involvement of parents in various pre-school activities and practical learning is important for a child in the acquisition of the curriculum. Parents need to contribute in developing various social skills of their children, which is the basis for successful learning of the curriculum. However, parents acknowledge that they lack accessible guidance on how to properly support children in learning compulsory pre-school education at home.

The results of the research reflect the need for parental involvement in establishing cooperation with the community outside the educational institution, its role in the child's development and facilitating the learning of the subject. The study indicates that pre-school institutions have difficulties with such environmental aspects of inclusive education as the lack of access to specialized staff and the environment, while parents emphasize that an individual learning approach is not provided for children with disabilities. All these aspects interact and are closely interlinked, which points to problems in the overall pre-school education system. It was pointed out that municipalities are in many cases 
uninterested in increasing capacity and capability of pre-school institutions to solve their issues. Pre-school teachers sometimes face mobbing on the part of parents regarding too high demands.

Further studies can be developed to understand how the pandemic situation has changed and influenced communication and collaboration patterns.

\section{Bibliography}

1. Āboltina L., Černova E. (2017). Pētījumi pirmsskolas pedagogijāa un to atspogulojums Latvijas Universitātes Rakstos [Reflection of Research in Pre-school Pedagogy in the Issues of University of Latvia Scientific Papers]. In I. Vilks (Ed.), Latvijas Universitātes raksti, 815. Zinātnuu vēsture un muzejniecība. Rīga: Latvijas Universitāte, 52-61. doi: 10.22364/luraksti.zvm.815.06 (in Latvian)

2. Badjanova J., Ilisko Dz. (2014). Holistic philosophy based teaching approaches in Latvian primary schools: Primary education teachers' view. In V. Dislere (Ed.), The Proceedings of the International Scientific Conference Rural Environment. Education. Personality (REEP), 7. Jelgava: LLU, 22-28. Retrieved from https://lufb.llu.lv/conference/REEP/2014/Latvia-UnivAgricult-REEP-2014proceedings-22-28.pdf

3. Barile N. (2020). Mastering the Parent-Teacher Meeting: Eight Powerful Tips. Retrieved from https://www.wgu.edu/heyteach/article/mastering-parent-teacher-meeting-eight-powerfultips 1612.html

4. Deans J., Klarin S., Liang R., Frydenberg E. (2017). All Children Have the Best Start in Life to Create a Better Future for Themselves and for the Nation. Australasian Journal of Early Childhood, 42(4), 78-86. doi: 10.23965/AJEC.42.4.09

5. Degangi A.G., Wietlibach S., Poisson S., Stein E., Royeen C. (1994). The Impact of Culture and Socioeconomic Status on Family-Professional Collaboration: Challenges and Solutions. Topics in Early Childhood Special Education, 14(4), 503-520. doi: 10.1177/027112149401400409

6. Diekmann A., Lindenberg S. (2001). Sociological Aspects of Cooperation. In N.J. Smelser, P.B. Baltes (Eds.), International Encyclopaedia of the Social Sciences. Pergamon, 2751-2756. doi: 10.1016/B0-08-043076-7/01847-7

7. Ecirli A. (2012). Preschool Education in Socialization of the Child. In the Proceedings of the Albania International Conference on Education (AICE), 1. Tirana, 208-212. Retrieved from http://dspace.epoka.edu.al/handle/1/782

8. Epstein J.L. (2010). School/Family/Community Partnerships: Caring for the Children We Share. Phi Delta Kappan, 92(3), 701-712. doi: 10.1177/003172171009200326

9. Klauža A., Kozaka Dz., Pagraba E., Smirnova I., Veispale K. (2009). Skolas un gimenes sadarbība [School and family cooperation]. Metodiskais līdzeklis. Retrieved from https://ausainais.files.wordpress.com/2009/12/audz_vjic_rik55.pdf (in Latvian)

10. Koviene S. (2017). Competence Conditions Enabling Education in Pre-school Education Establishments: Parents' Evaluation. Problems of Education in the 21st Century, 75(2), 157-169. Retrieved from http://www.scientiasocialis.lt/pec/node/files/pdf/vol75/157-169.Koviene_Vol.75-2_PEC.pdf

11. Lin J., Napoli A.R., Schmitt S.A., Purpura D.J. (2021). The Relation Between Parent Ratings and Direct Assessments of Preschoolers' Numeracy Skills. Learning and Instruction, 71, 101375. doi: 10.1016/j.learninstruc.2020.101375

12. Noteikumi par valsts pirmsskolas izglītības vadlīnijām un pirmsskolas izglìtības programmu paraugiem [Regulations on State Pre-school Education Guidelines and Sample Pre-school Education Programs]. (2018). Rīga: Ministru kabineta noteikumi Nr. 716. Retrieved from https://likumi.lv/ta/id/303371 (in Latvian)

13. Reynolds A.J., Hayakawa M., Ou S.R., Mondi C.F., Englund M.M., Candee A.J., Smerillo N.E. (2017). Scaling and Sustaining Effective Early Childhood Programs Through School-FamilyUniversity Collaboration. Child Development. 88(5), 1453-1465. doi: 10.1111/cdev.12901

14. Robbins J. (2005). Contexts, Collaboration, and Cultural Tools: A Sociocultural Perspective on Researching Children's Thinking. Contemporary Issues in Early Childhood, 6(2), 140-149. doi: 10.2304/ciec.2005.6.2.4

15. Roberts D.L., Allen J.P. (2015). Exploring Ethical Issues Associated with Using Online Surveys in Educational Research. Educational Research and Evaluation, 21(2), 95-108.

doi: 10.1080/13803611.2015.1024421 
16. Sanders M.G., Epstein J.L. (1998). School-Family-Community Partnerships in Middle and High Schools: From Theory to Practice. Report No. 22. Retrieved from https://files.eric.ed.gov/fulltext/ED423330.pdf

17. Taurina A. (2015). Pre-school Age Child Treatment and Awareness about Conservancy of Nature. In V. Dislere (Ed.), The Proceedings of the International Scientific Conference Rural Environment. Education. Personality (REEP), 8. Jelgava: LLU, 65-73. Retrieved from https://llufb.llu.lv/conference/REEP/2015/Latvia-Univ-Agricult-REEP-2015proceedings-65-73.pdf

18. Toepoel V. (2016). Doing Surveys Online. London: SAGE Publications. Retrieved from https://uk.sagepub.com/sites/default/files/upmbinaries/71933_Toepoel_Doing_Surveys_Online.pdf

19. Vanaga A., Balode M. (2016). Succession of Fostering Learning Skills in Preschool and School. In V. Dislere (Ed.), The Proceedings of the International Scientific Conference Rural Environment. Education. Personality (REEP), 9. Jelgava: LLU, 114-121. Retrieved from https://llufb.llu.lv/conference/REEP/2016/Latvia-Univ-Agricult-REEP-2016proceed2255-808X114-121.pdf

20. Yaşaroğlu C. (2016). Cooperation and Importance of School and Family on Values Education. European Journal of Multidisciplinary Studies. 1(2), 66-71. doi: 10.26417/ejms.v1i2.p66-71 